\title{
SOIL WATER DYNAMICS OF CROPLANDS AND ORCHARDS AFTER LAND RECLAMATION IN THE WEIBEI AREA, NORTHWEST CHINA
}

\author{
ZHANG, L. ${ }^{1,2,3,4}-$ WANG, Y. Q. ${ }^{1,2,3,4 *}$ \\ ${ }^{1}$ Shaanxi Provincial Land Engineering Construction Group Co. Ltd., Xi'an 710075, China \\ ${ }^{2}$ Shaanxi Key Laboratory of Land Consolidation, Xi'an 710064, China \\ ${ }^{3}$ Institute of Land Engineering and Technology, Shaanxi Provincial Land Engineering \\ Construction Group Co., Ltd., Xi'an 710021, China \\ ${ }^{4}$ Key Laboratory of Degraded and Unused Land Consolidation Engineering, The Ministry of \\ Natural Resources, Xi'an 710021, China \\ *Corresponding author \\ e-mail: luluqiaofeng@.com
}

(Received $18^{\text {th }}$ Oct 2019; accepted $23^{\text {rd }}$ Jan 2020)

\begin{abstract}
This study compared the soil water characteristics of croplands (wheat) and orchards (apple orchard) after the reclamation of hollow villages in the Weibei rainfed highland in Shaanxi Province, China. Soil water content in the $0-150 \mathrm{~cm}$ soil profile was monitored during apple tree growth from March to September in 2018. The results showed that the water content of different soil layers varied through time and space in both croplands and orchards. Soil water content was significantly higher in orchards than croplands, whereas soil water stress exhibited an inverse trend. A significant drought occurred in the $0-120 \mathrm{~cm}$ soil profile of croplands from mid-April to mid-July, especially before the rainy season (mid-May to mid-July). Water stress was most likely to occur at the $20-60 \mathrm{~cm}$ soil depth. There were 78 days of soil water stress in the $20-40 \mathrm{~cm}$ soil layer, and soil water content was below the permanent wilting coefficient for 42 days in the $40-60 \mathrm{~cm}$ soil layer. Therefore, orchards are more sustainable than croplands for agricultural production after the rehabilitation of hollow villages in the Weibei area, and the development of a tree-fruit industry here is reasonable.
\end{abstract}

Keywords: soil water, wheat field, apple orchard, spatiotemporal dynamics, water stress

\section{Introduction}

Hollow villages have long been a problem in China, which are the result of rural residents leaving their villages in search of employment in large cities (Cheng et al., 2001; $\mathrm{Xu}, 2004 ; \mathrm{Li}$ and $\mathrm{Li}, 2008$ ). In response to this phenomenon, the Chinese government implemented a series of land reclamation policies (Wang, 2019; Guo et al., 2005; Fan et al., 2011; Qian et al., 2011; Chen et al., 2014).

Previous research has investigated the spatial characteristics of hollow villages (Wang et al., 2005), their evolutionary features (Xue and $\mathrm{Wu}, 2001$ ), causes of formation (Zhong, 2008), and potential effects (Lei, 2002; Feng and Chen, 2003). It was affirmed that the reclamation of hollow villages increased agricultural land use and improved the living environment of local residents (Zhu et al., 2010). However, not knowing how to use the land after reclamation has plagued people. Soil water status is one of the most important factors for determining the suitability of different land uses (Vachaud et al., 1985; Grayson and Western, 1998; Kim and Barros, 2002; Jacobs et al., 
2004; Vereecken et al., 2007; Famiglietti et al., 2008; Guber et al., 2008; Brocca et al., 2010; Wang et al., 2012).

The Weibei rainfed highland has experienced a transformation of agricultural production from crops to fruits. In this study, we determined the spatial and temporal variability of soil water by monitoring the soil water profile in croplands and orchards after the reclamation of hollow villages. Our results could be useful for the selection of appropriate land uses in the Weibei rainfed highland after the reclamation of hollow villages.

\section{Materials and methods}

\section{Study area}

The study area was located in Yuandi Town, Xunyi County, Shaanxi Province, China $\left(\mathrm{E} 108^{\circ} 08^{\prime}-108^{\circ} 52^{\prime}, \mathrm{N} 34^{\circ} 57^{\prime}-35^{\circ} 33^{\prime}\right)$. The hollow village had been under reclamation for 20 years in the northern boundary of Guanzhong Plain (Fig. 1). The terrain is relatively complex being mountainous in the northeast with lowlands in the southwest. The area is a typical loess plateau gully in terms of landform type, and it is cut into four north-south loess ridges by gullies. The ridges were wide and flat. The soil type is mainly black loess. The top-loose and bottom-compacted soil structure shows the features of "Mengjin (gold-covered)" soil profile configuration, with a high capability for water and fertility conservation (Dörner et al., 2015). The deep and loose geological conditions can meet the growth requirements of crops and fruit trees.
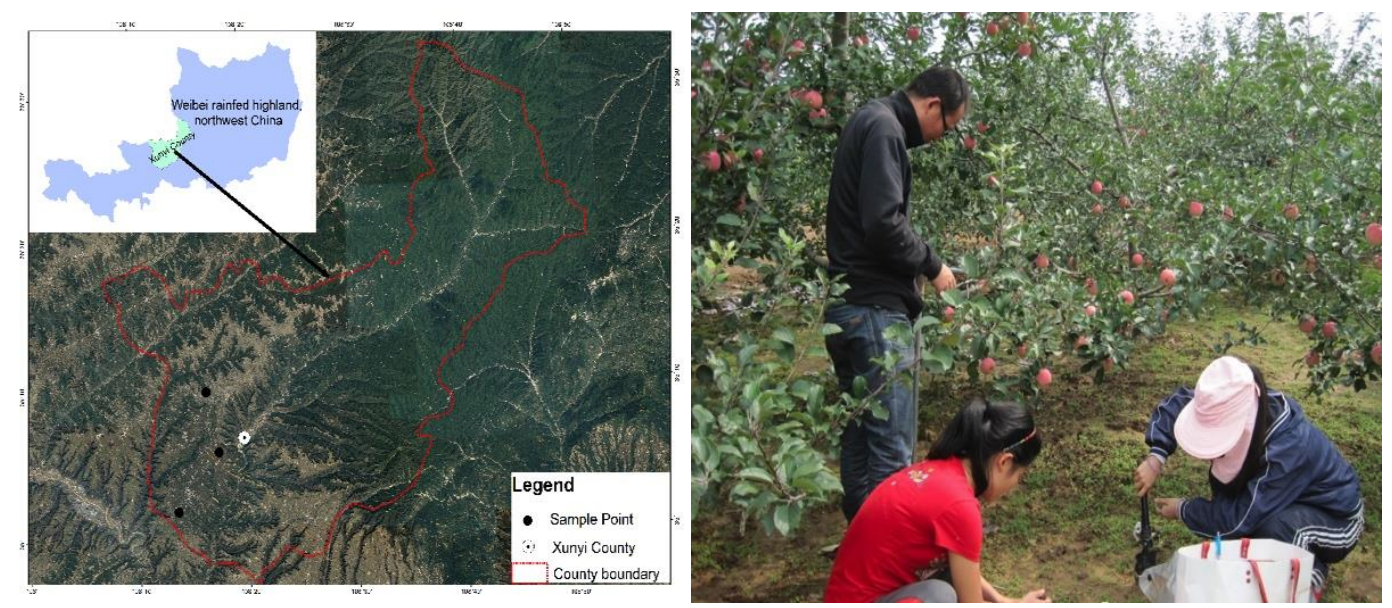

Figure 1. Sampling area chart

The Yuandi Town hollow village land reclamation project area included abandoned and vacant homesteads throughout the territory. The project mainly included leveling land, irrigation installation, field road construction, cropland shelterbelts, and other projects. One focus was the land leveling project, in which the old walls around the hollow villages were leveled, plowed, and reclaimed as agricultural land with a slope that could ensure the uniformity for irrigation. A balanced fertilization method was used to establish the tillage layer of cropland or orchard in the reclaimed land, in order to meet the growth requirements of crops or fruit trees. The topsoil of the reclaimed land 
contained: organic matter, 9.7-11.7 $\mathrm{g} \cdot \mathrm{kg}^{-1}$; total nitrogen, $0.4-1.0 \mathrm{~g} \cdot \mathrm{kg}^{-1}$; total phosphorous, $1.5-1.6 \mathrm{~g} \cdot \mathrm{kg}^{-1}$; and total potassium, $21.2-24.2 \mathrm{~g} \cdot \mathrm{kg}^{-1}$.

\section{Sample collection}

To monitor soil water, three fields of winter wheat were selected after the reclamation of hollow villages in Yuandi Town. The winter wheat cultivar tested was Triticum aestivum L., whose growth period lasts from October to June of the following year. In addition, three young apple orchards ( $<10$ years old) were selected in the same vicinity of the wheat fields. The apple variety tested was Malus domestica Borkh. 'Red Fuji', whose growth period lasts 184 days from mid-March to mid-September. Wheat fertilization was performed by a single application of all fertilizers as basal dressing during soil preparation, whereas apple tree fertilization was applied by ditching. There were no other plants or weeds covering the ground of croplands or orchards.

Soil samples were collected with a $6 \mathrm{~cm}$-diameter soil drill once a month from March (leaf budding) through September (apple harvest) in 2018. For each treatment, three replicate plots $(500 \mathrm{~m} \times 400 \mathrm{~m}$ per plot) were sampled. In each plot, five points were randomly selected in a plum-blossom pattern (Fig. 2), and each sampling unit was smaller than 20 ha. The replicate samples from three plots were mixed and five replications per treatment were obtained. Three soil samples from the same soil layer were mixed to form a composite sample of the eight soil layers along the $0-150 \mathrm{~cm}$ profile $(0-10 \mathrm{~cm}, 10-20 \mathrm{~cm}, 20-40 \mathrm{~cm}, 40-60 \mathrm{~cm}, 60-80 \mathrm{~cm}, 80-100 \mathrm{~cm}, 100-120 \mathrm{~cm}$, and $120-150 \mathrm{~cm})$.

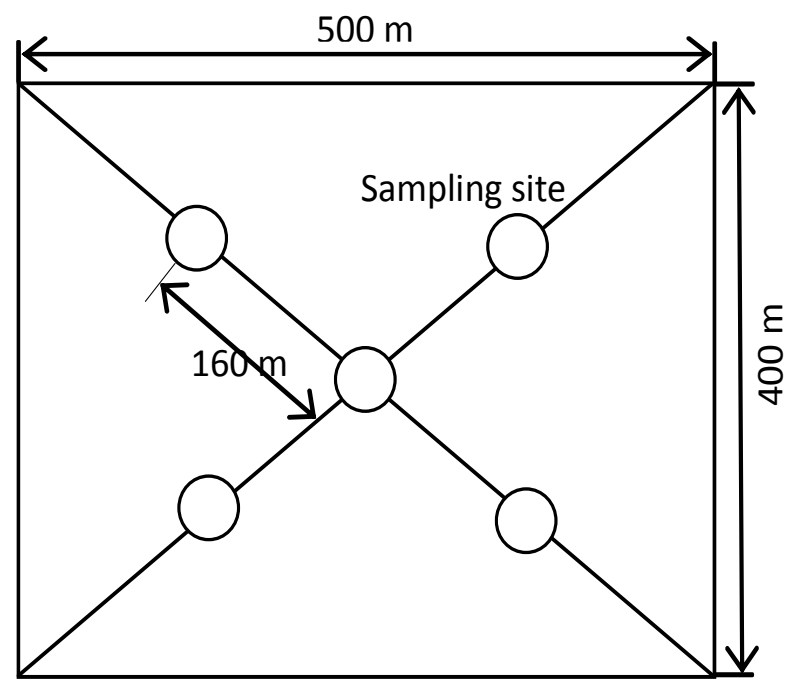

Figure 2. Distribution of soil sampling points in each plot

\section{Test methods}

The soil samples were transported to the laboratory within $2 \mathrm{~h}$ of collection and immediately weighed using an electronic balance $(0.0001 \mathrm{~g})$ upon arrival. Soil water content of each soil layer was determined by oven-drying at $105^{\circ} \mathrm{C}$ for $24 \mathrm{~h}$ (Gardner, 1965). Then, the $60 \%$ field capacity in each soil layer was calculated (Table 1), which was equivalent to the soil water stress point, or the capillary fracture water content (Chen et al., 2008). 
Table 1. The field capacity of each soil layer in Weibei rainfed highland $(\% v)$

\begin{tabular}{c|c|c|c|c}
\hline \multicolumn{2}{c|}{ Soil layer (cm) } & Field capacity & 60\% field capacity & Permanent wilting coefficient \\
\hline \multirow{4}{*}{ Covering soil } & $0-10$ & $25.56 \pm 2.5319$ & $15.34 \pm 1.5624$ & $11.12 \pm 0.9542$ \\
& $10-20$ & $25.56 \pm 1.0242$ & $15.34 \pm 1.2306$ & $11.12 \pm 1.1240$ \\
& $20-40$ & $25.56 \pm 2.1648$ & $15.34 \pm 1.6417$ & $10.80 \pm 0.8256$ \\
\hline \multirow{2}{*}{ Dark loessial } & $40-60$ & $28.65 \pm 2.8901$ & $17.19 \pm 1.2492$ & $13.14 \pm 0.9408$ \\
& $60-80$ & $28.65 \pm 1.8726$ & $17.19 \pm 1.6741$ & $13.04 \pm 1.1506$ \\
\hline \multirow{4}{*}{ Loess subsoil } & $80-100$ & $27.41 \pm 2.6034$ & $16.45 \pm 2.4825$ & $11.20 \pm 0.9402$ \\
& $100-120$ & $27.76 \pm 2.2217$ & $16.65 \pm 1.0348$ & $11.64 \pm 1.1203$ \\
& $120-150$ & $27.76 \pm 1.4563$ & $16.65 \pm 1.5607$ & $11.66 \pm 1.2056$ \\
\hline
\end{tabular}

Data are means \pm standard deviation $(\mathrm{n}=5)$

Daily rainfall was measured in Xunyi for 2018 using a SDM6A stainless ombrometer (Fenghai, Tianjin, China). Monthly values were calculated from the daily values for January to November (Fig. 3). The year 2018 was a normal water year, in which the rainfall from July to September accounted for $60.4 \%$ of total annual rainfall. The total rainfall was $569.1 \mathrm{~mm}$ over the growth period of apple from growth initiation in March to fruit harvest in September 2018 (Xunyi County Chronicle Compilation Committee, 2018).

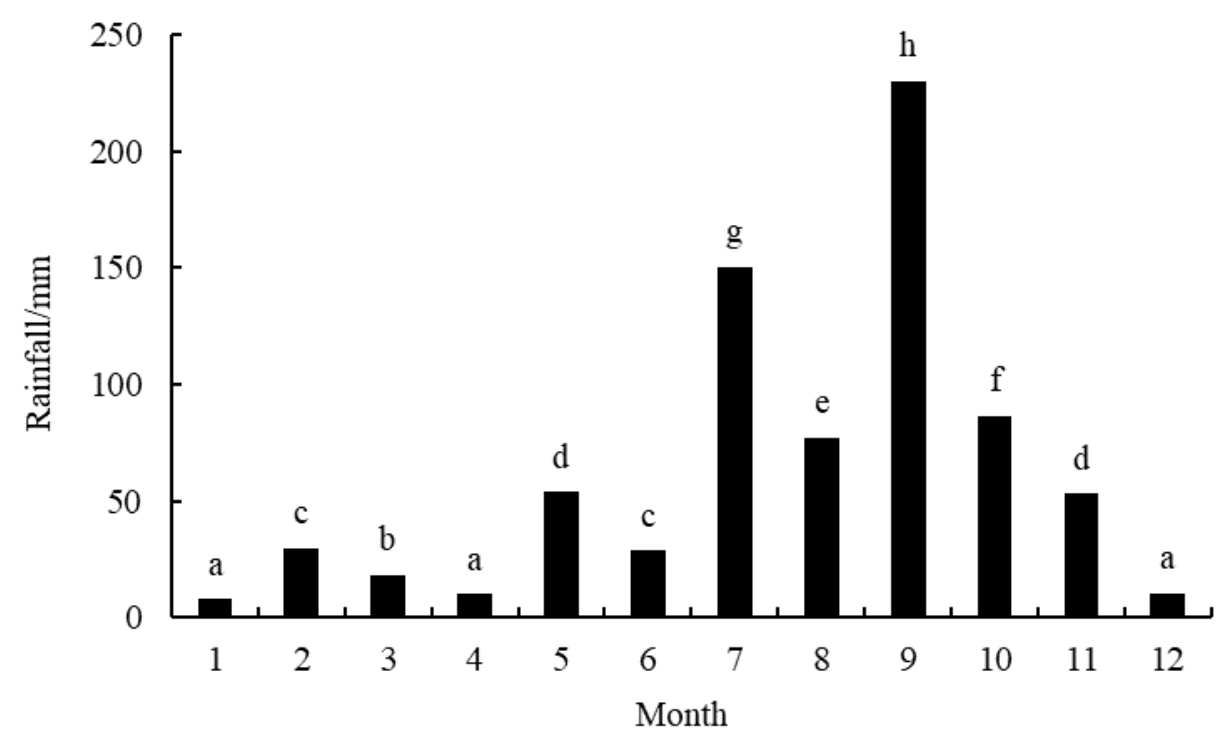

Figure 3. Monthly precipitation in Xunyi County, Shaanxi Province, China for 2018 ( $n=3$, based on daily rainfall measured using a stainless ombrometer from January to November)

\section{Data analysis}

To evaluate soil water changes during crop growth, soil water content and its changes were divided into four states using the field capacity, $60 \%$ field capacity, and permanent wilting coefficient as thresholds (Table 2). Then the percentage of days of each water state in apple growth period (184 days) was calculated for croplands and 
orchards to quantitatively analyze the soil water status under different land use types. Mathematical modeling was carried out using Excel 2016 to simulate the process of changes of soil water content in each soil layer during apple tree growth.

Table 2. Water content and evaluation indexes

\begin{tabular}{c|c}
\hline Soil water range & Evaluation of water status \\
\hline Greater than field capacity & Water excess state (waterlogging) \\
\hline $\begin{array}{c}\text { Between the field capacity and 60\% of field capacity } \\
\text { coefficient }\end{array}$ & Easy to use state of water \\
\hline Less than permanent wilting coefficient & $\begin{array}{c}\text { Water stress state } \\
\text { Invalid state of water (drought to } \\
\text { death) }\end{array}$ \\
\hline
\end{tabular}

When the soil water content exceeded field capacity, the oxygen supply was limited and drainage was needed. The most preferable state of water supply was when the soil water content was between field capacity and capillary fracture water content (equivalent to $60 \%$ of field capacity). Water stress became greater as it got closer to the permanent wilting coefficient, which was considered the state of drought and death. If the duration of water stress was short, then some drought-tolerant crops may recover, but if water stress occurs too long than even rehydrated plants will not recover.

Data are means \pm standard deviation $(n=5)$. Statistical analysis was performed by $t-$ test with SPSS Statistics 18.0 (SPSS Inc., Chicago, USA). A P value of less than 0.05 was considered to indicate statistical significance.

\section{Results and discussion}

\section{Analysis of temporal and spatial changes in soil water content}

Figure 4 illustrates the process of changes of soil water content through time and space for croplands and orchards during apple tree growth. After a long winter, in the spring stage, the soil water content of croplands in the $0-10 \mathrm{~cm}$ soil layer was $1.92 \%$ lower than that of the orchards (Fig. 4a). This result indicates that although the apple trees shed their leaves in winter, the dense trunks changed the wind speed and temperature near the ground, which could reduce the loss of soil water. During the whole growth period of apple trees, the water content of the $0-10 \mathrm{~cm}$ soil layer in orchards was always higher than that of croplands, and mostly in the most comfortable state of water. In croplands, the soil water content was in water stress or transient drought for 4 months, and the decline of soil water content was most obvious from March to April when soil water content fell below the permanent wilting coefficient. However, the drought was less serious in orchards. The maximal relative difference in soil water content between croplands and orchards occurred at the end of April when the sustained drought was most severe, and the soil water content of orchards was $56.04 \%$ higher than that of croplands. The minimal relative difference was found in August during the rainy season, with the soil water content of orchards being $10.03 \%$ higher than that of croplands. The difference in soil water content was generally large in the drought period, while it became smaller difference during the compensatory period of soil water. 

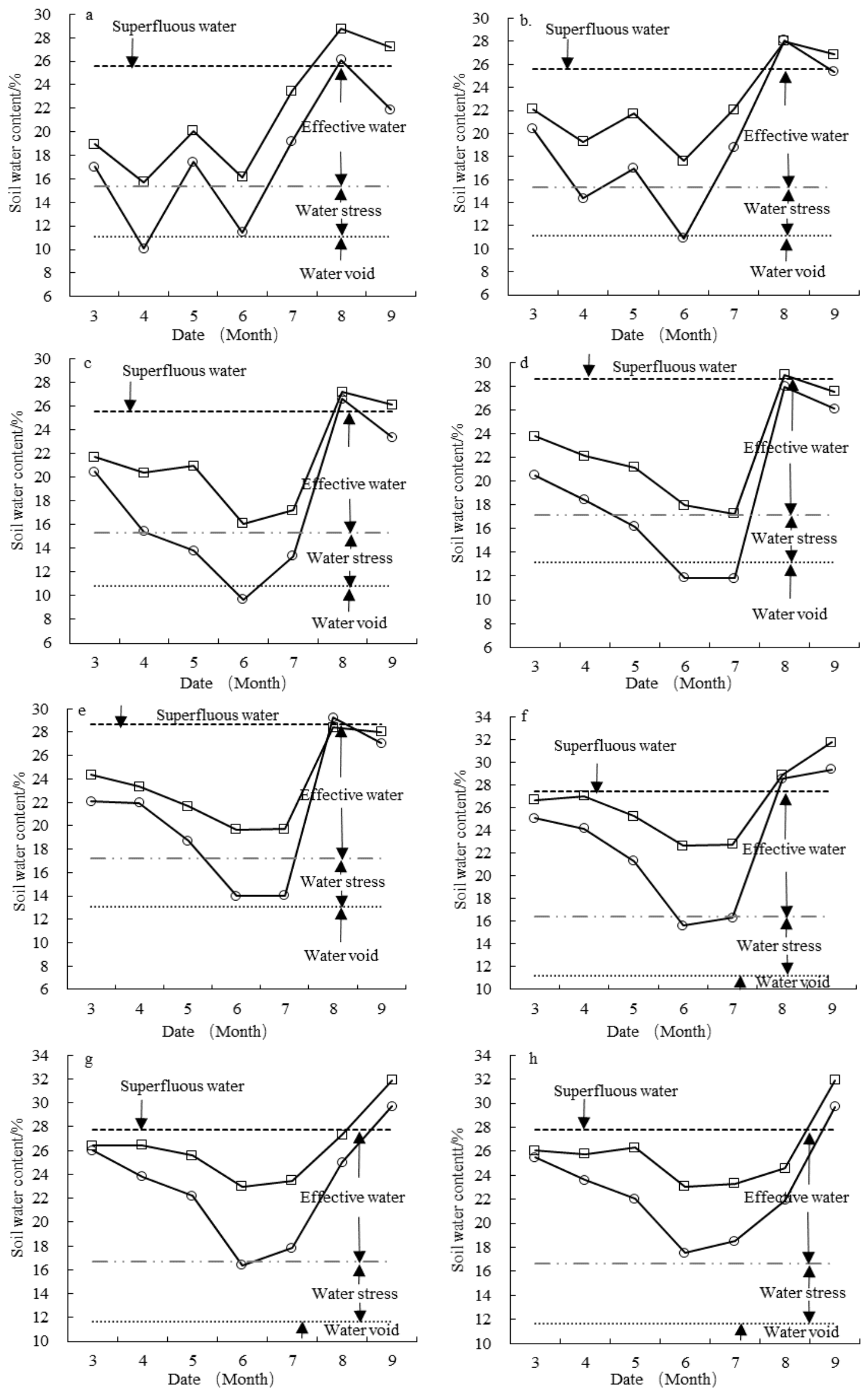

APPLIED ECOLOGY AND ENVIRONMENTAL RESEARCH 18(1):1783-1797.

http://www.aloki.hu • ISSN 15891623 (Print) • ISSN 17850037 (Online)

DOI: http://dx.doi.org/10.15666/aeer/1801_17831797 


\begin{tabular}{|c|c|c|c|}
\hline \multirow[t]{2}{*}{ Legend } & Field capacity & $\begin{array}{c}-\cdots-\cdots- \\
60 \% \text { Field capacity }\end{array}$ & $\begin{array}{l}\text { Permanent wilting } \\
\text { coefficient }\end{array}$ \\
\hline & $\overline{\text { Croplands }}$ & $\overline{\text { Orchards }}$ & \\
\hline
\end{tabular}

Figure 4. Changes in soil water content with time in 0 to $150 \mathrm{~cm}$ profile (a) $0-10 \mathrm{~cm}$ soil layer, (b) 10-20 cm soil layer, (c) 20-40 cm soil layer, (d) 40-60 cm soil layer, (e) 60-80 cm soil layer, $(f) 80-100 \mathrm{~cm}$ soil layer, $(\mathrm{g}) 100-120 \mathrm{~cm}$ soil layer, (h) $120-150 \mathrm{~cm}$ soil layer

In the 10-20 cm soil layer (Fig. 4b), the water content of the croplands was also consistently lower than that of orchards. The soil water content of orchards varied between field capacity and capillary water content, which was in a suitable state of water condition. However, the water content of 10-20 cm soil layer in croplands continued to decline from the beginning of spring and did not gradually recover until mid-June before the rainy season. The maximal relative difference in soil water content between croplands and orchards occurred in mid-June, when the soil water content of orchards was $61.40 \%$ higher than that of croplands. The minimal relative difference appeared in August, with the soil water content of orchards being 0.35\% higher than that of croplands. The difference in soil water content diminished in the rainy season compared with the drought period. In the $20-40 \mathrm{~cm}$ soil layer (Fig. 4c), the temporal changes in soil water content of croplands and orchards were synchronous with the change in the upper soil layer $(0-20 \mathrm{~cm})$. However, the effect of weak rainfall on soil water content was negligible and did not have a significant trend like the $0-20 \mathrm{~cm}$ soil layer. In the $20-40 \mathrm{~cm}$ soil layer, the maximal relative difference in soil water content between croplands and orchards occurred in May, $7.15 \%$, whereas the minimal difference appeared in August, 0.59\%.

Compared with the upper and lower soil layers, the 40-60 cm soil layer showed the highest degree of desiccation during apple tree growth (Fig. 4d). The maximal relative difference in soil water content between croplands and orchards occurred in June, and a $51.68 \%$ increase was found in the soil water content of orchards relative to croplands. The minimal relative difference appeared in August, with the soil water content of orchards being $3.55 \%$ higher than that of croplands. The characteristics of water consumption and compensatory period of water change in the $60-80 \mathrm{~cm}$ soil layer were also obvious (Fig. 4e). The greatest difference of water content occurred in June $(5.69 \%)$, and the minimal difference occurred in August $(0.86 \%)$. The soil water content of croplands was lower than that of orchards, but the relative difference in soil water content between different land use types was reduced in this soil layer. The largest relative increase in soil water content of orchards relative to croplands was $40.64 \%$.

The soil calcium layer and the loess parent layer occurred at deeper soil depths. During the growth period of apple trees, the deep soil water content of croplands and orchards changed in the most comfortable state between field capacity and capillary water content, and there was no problem of drought stress. The compensation period of deep soil water also lagged about 1 month behind soil layers above $40 \mathrm{~cm}$ (Fig. $4 f, g, h$ ). At the end of the rainy season, the soil water compensation amount had been significantly higher than the field capacity, which will inevitably move further into the deeper soil layer. The greatest difference in soil water content in the $60-80 \mathrm{~cm}$ soil layer between croplands and orchards occurred in June (7.01\%), and the minimal difference 
occurred in August $(0.36 \%)$. The maximal relative increase in soil water content of orchards relative to croplands reached $44.83 \%$ in the $80-100 \mathrm{~cm}$ soil layer, $40.52 \%$ in the $100-120 \mathrm{~cm}$ soil layer, and $31.46 \%$ in the $120-150 \mathrm{~cm}$ soil layer.

Through the layer-by-layer analysis of the variation of soil water content over time in croplands and orchards after many years of reclamation in Weibei area, we found that the effect of vegetation on the water content of the soil profile can be reflected across the whole $0-150 \mathrm{~cm}$ gradient, but the difference decreased with increased soil depth. The cropland soil had a relatively heavy and long-term drought in the middle and deep soil layers, but this drought was temporary with the arrival of the rainy season. However, the soil water content of the orchard was always higher than that of croplands during the growth period, there was almost no obvious water stress, and no internal dry soil layer was found within the spatial scale of the study.

\section{Mathematical simulation of soil water change process}

In any case, soil water is a process of fluctuation. The effects of water stress or severe water deficiency on plant growth processes depend not only on the severity of stress and water scarcity, but more importantly on the duration of stress and scarcity. The greater the degree of stress and deficiencies, the greater the harm to plants, the longer the continuous stagnation, the more likely the plant to die in drought even if rehydrated. Thus, this paper took the soil water constant as the threshold and the duration of the soil water content (d) as the index to quantitatively analyze the soil water status of croplands and orchards after the reclamation of hollow villages.

To improve the reliability of the quantitative analysis results, it was first necessary to carry out mathematical simulations of the process of changing the soil water content of each soil layer during the growth period of apple trees (Fig. 4). The model was mainly to change the line graph of the soil water content change process in various soil layers of Figure 4 into curves to more accurately calculate the soil water change. The statistical results were shown in Table 3.

Table 3. The mathematical simulation of soil water change in different cover conditions in Weibei

\begin{tabular}{|c|c|c|c|c|}
\hline \multirow{2}{*}{$\begin{array}{c}\text { Soil layer } \\
(\mathbf{c m})\end{array}$} & \multicolumn{2}{|l|}{ Cropland } & \multicolumn{2}{|l|}{ Orchard } \\
\hline & Model & $R^{2}$ & Model & $R^{2}$ \\
\hline $0-10$ & $y=17.84+5.90 \sin \left(\frac{2 \pi x}{7.62}+2.52\right)$ & 0.6836 & $y=22.17+5.88 \sin \left(\frac{2 \pi x}{8.87}+2.96\right)$ & 0.8299 \\
\hline $10-20$ & $y=19.57+7.00 \sin \left(\frac{2 \pi x}{7.41}+2.07\right)$ & 0.7891 & $y=23.28+4.44 \sin \left(\frac{2 \pi x}{8.71}-3.70\right)$ & 0.7579 \\
\hline $20-40$ & $y=17.20+7.10 \sin \left(\frac{2 \pi x}{6.65}+1.43\right)$ & 0.8169 & $y=20.35+4.55 \sin \left(\frac{2 \pi x}{0.45}-0.91\right)$ & 0.6370 \\
\hline $40-60$ & $y=19.50+7.27 \sin \left(\frac{2 \pi x}{7.53}+1.73\right)$ & 0.7023 & $y=21.58+4.81 \sin \left(\frac{2 \pi x}{4.93}+5.79\right)$ & 0.6624 \\
\hline $60-80$ & $y=19.41+7.04 \sin \left(\frac{2 \pi x}{4.76}+5.52\right)$ & 0.7635 & $y=24.35+4.5 \sin \left(\frac{2 \pi x}{1.14}+1.1\right)$ & 0.7455 \\
\hline $80-100$ & $y=21.41+6.68 \sin \left(\frac{2 \pi x}{5}-5.37\right)$ & 0.8525 & $y=25.61+3.84 \sin \left(\frac{2 \pi x}{4.96}+5.56\right)$ & 0.7746 \\
\hline $100-120$ & $y=21.93+5.55 \sin \left(\frac{2 \pi x}{5.54}-0.069\right)$ & 0.8857 & $y=12.54+12510 \sin \left(\frac{2 \pi x}{629.2}+4.68\right)$ & 0.8098 \\
\hline $120-150$ & $y=22+4.77 \sin \left(\frac{2 \pi x}{0.014}+0.15\right)$ & 0.8324 & $y=20.47+20450 \sin \left(\frac{2 \pi x}{834.2}+4.69\right)$ & 0.6345 \\
\hline
\end{tabular}

In the model, $y$ is the water content $(\%)$ in xth measured, $x$ is the cumulative number of measured water content in the field 
Using the soil water change model in Table 3 and the proposed soil water state interval index in Table 2, we calculated the daily soil water state for croplands and orchards layer by layer, the results of which were shown in Tables 4 and 5.

Table 4. The analysis of soil water status in $0-150 \mathrm{~cm}$ soil profile of Weibei croplands

\begin{tabular}{|c|c|c|c|c|c|c|c|c|}
\hline \multirow[b]{2}{*}{$\begin{array}{l}\text { Soil layer } \\
(\mathrm{cm})\end{array}$} & \multirow[b]{2}{*}{$\begin{array}{c}\text { Water status and } \\
\text { evaluation }\end{array}$} & \multicolumn{6}{|c|}{ Monthly water status (days) } & \multirow{2}{*}{$\begin{array}{c}\text { Percentage of } \\
\text { days in apple } \\
\text { growth period } \\
(\%)\end{array}$} \\
\hline & & $\begin{array}{l}3 / 15- \\
4 / 15\end{array}$ & $\begin{array}{l}4 / 16- \\
5 / 15\end{array}$ & $\begin{array}{l}5 / 16- \\
6 / 15\end{array}$ & $\begin{array}{r}6 / 16- \\
7 / 15\end{array}$ & $\begin{array}{l}7 / 16- \\
8 / 15\end{array}$ & $\begin{array}{l}8 / 16- \\
9 / 15\end{array}$ & \\
\hline \multirow{4}{*}{$0-10$} & Superfluous water & 0 & 0 & 0 & 0 & 3 & 4 & 3.80 \\
\hline & Effective water & 8 & 9 & 11 & 15 & 28 & 27 & 53.26 \\
\hline & Water stress & 21 & 17 & 20 & 15 & 0 & 0 & 39.67 \\
\hline & Unavailable water & 2 & 4 & 0 & 0 & 0 & 0 & 3.27 \\
\hline \multirow{4}{*}{$10-20$} & Superfluous water & 0 & 0 & 0 & 0 & 8 & 29 & 20.10 \\
\hline & Effective water & 26 & 19 & 8 & 7 & 23 & 2 & 46.20 \\
\hline & Water stress & 5 & 11 & 22 & 22 & 0 & 0 & 32.61 \\
\hline & Unavailable water & 0 & 0 & 1 & 1 & 0 & 0 & 1.09 \\
\hline \multirow{4}{*}{$20-40$} & Superfluous water & 0 & 0 & 0 & 0 & 2 & 10 & 6.52 \\
\hline & Effective water & 31 & 1 & 0 & 0 & 24 & 21 & 41.85 \\
\hline & Water stress & 0 & 29 & 23 & 21 & 5 & 0 & 42.39 \\
\hline & Unavailable water & 0 & 0 & 8 & 9 & 0 & 0 & 9.24 \\
\hline \multirow{4}{*}{$40-60$} & Superfluous water & 0 & 0 & 0 & 0 & 0 & 0 & 0 \\
\hline & Effective water & 31 & 16 & 0 & 0 & 21 & 31 & 53.80 \\
\hline & Water stress & 0 & 14 & 22 & $\mathbf{0}$ & 7 & 0 & 23.37 \\
\hline & Unavailable water & 0 & 0 & 9 & 30 & 3 & 0 & 22.83 \\
\hline \multirow{4}{*}{$60-80$} & Superfluous water & 0 & 0 & 0 & 0 & 1 & 8 & 4.89 \\
\hline & Effective water & 31 & 30 & 10 & 0 & 24 & 23 & 64.13 \\
\hline & Water stress & 0 & 0 & 21 & 30 & 6 & 0 & 30.98 \\
\hline & Unavailable water & 0 & 0 & 0 & 0 & 0 & 0 & $\mathbf{0}$ \\
\hline \multirow{4}{*}{$80-100$} & Superfluous water & 0 & 0 & 0 & 0 & 3 & 31 & 18.48 \\
\hline & Effective water & 31 & 30 & 27 & 5 & 28 & 0 & 65.76 \\
\hline & Water stress & 0 & 0 & 4 & 25 & 0 & 0 & 15.76 \\
\hline & Unavailable water & 0 & 0 & 0 & 0 & 0 & 0 & $\mathbf{0}$ \\
\hline \multirow{4}{*}{$100-120$} & Superfluous water & 0 & 0 & 0 & 0 & 0 & 25 & 13.59 \\
\hline & Effective water & 31 & 30 & 30 & 24 & 31 & 6 & 82.61 \\
\hline & Water stress & 0 & 0 & 1 & 6 & 0 & 0 & 3.80 \\
\hline & Unavailable water & 0 & 0 & 0 & 0 & 0 & 0 & $\mathbf{0}$ \\
\hline \multirow{4}{*}{$120-150$} & Superfluous water & 0 & 0 & 0 & 0 & 0 & 8 & 4.35 \\
\hline & Effective water & 31 & 30 & 31 & 30 & 31 & 23 & 95.65 \\
\hline & Water stress & 0 & 0 & 0 & 0 & 0 & 0 & $\mathbf{0}$ \\
\hline & Unavailable water & 0 & 0 & 0 & 0 & 0 & 0 & $\mathbf{0}$ \\
\hline
\end{tabular}


Table 5. The analysis of soil water status in $0-150 \mathrm{~cm}$ soil profile of Weibei orchards

\begin{tabular}{|c|c|c|c|c|c|c|c|c|}
\hline \multirow{2}{*}{$\begin{array}{l}\text { Soil layer } \\
\quad(\mathbf{c m})\end{array}$} & \multirow{2}{*}{$\begin{array}{l}\text { Water status and } \\
\text { evaluation }\end{array}$} & \multicolumn{6}{|c|}{ Monthly water status (d) } & \multirow{2}{*}{$\begin{array}{l}\text { Percentage of days } \\
\text { in apple growth } \\
\text { period }(\%)\end{array}$} \\
\hline & & $\begin{array}{c}3 / 15- \\
4 / 15 \\
\end{array}$ & $\begin{array}{c}4 / 16- \\
5 / 15 \\
\end{array}$ & $\begin{array}{c}5 / 16- \\
6 / 15\end{array}$ & $\begin{array}{l}6 / 16- \\
7 / 15\end{array}$ & $\begin{array}{l}7 / 16- \\
8 / 15\end{array}$ & $\begin{array}{l}8 / 16- \\
9 / 15\end{array}$ & \\
\hline \multirow{4}{*}{$0-10$} & Superfluous water & 0 & 0 & 0 & 0 & 19 & 31 & 27.17 \\
\hline & Effective water & 31 & 30 & 31 & 30 & 12 & 0 & 72.83 \\
\hline & Water stress & 0 & 0 & 0 & 0 & 0 & 0 & $\mathbf{0}$ \\
\hline & Unavailable water & 0 & 0 & 0 & 0 & 0 & 0 & $\mathbf{0}$ \\
\hline \multirow{4}{*}{$10-20$} & Superfluous water & 0 & 0 & 0 & 0 & 4 & 31 & 19.02 \\
\hline & Effective water & 31 & 30 & 31 & 30 & 27 & 0 & 80.98 \\
\hline & Water stress & 0 & 0 & 0 & 0 & 0 & 0 & $\mathbf{0}$ \\
\hline & Unavailable water & 0 & 0 & 0 & 0 & 0 & 0 & $\mathbf{0}$ \\
\hline \multirow{4}{*}{$20-40$} & Superfluous water & 0 & 0 & 0 & 0 & 5 & 31 & 19.57 \\
\hline & Effective water & 31 & 30 & 31 & 30 & 26 & 0 & 80.43 \\
\hline & Water stress & 0 & 0 & 0 & 0 & 0 & 0 & $\mathbf{0}$ \\
\hline & Unavailable water & 0 & 0 & 0 & 0 & 0 & 0 & $\mathbf{0}$ \\
\hline \multirow{4}{*}{$40-60$} & Superfluous water & 0 & 0 & 0 & 0 & 1 & 7 & 4.35 \\
\hline & Effective water & 31 & 30 & 31 & 30 & 30 & 24 & 95.65 \\
\hline & Water stress & 0 & 0 & 0 & 0 & 0 & 0 & $\mathbf{0}$ \\
\hline & Unavailable water & 0 & 0 & 0 & 0 & 0 & 0 & $\mathbf{0}$ \\
\hline \multirow{4}{*}{$60-80$} & Superfluous water & 0 & 0 & 0 & 0 & 0 & 0 & 0 \\
\hline & Effective water & 31 & 30 & 31 & 30 & 31 & 31 & 100 \\
\hline & Water stress & 0 & 0 & 0 & 0 & 0 & 0 & 0 \\
\hline & Unavailable water & 0 & 0 & 0 & 0 & 0 & 0 & $\mathbf{0}$ \\
\hline \multirow{4}{*}{$80-100$} & Superfluous water & 0 & 0 & 0 & 0 & 8 & 31 & 21.20 \\
\hline & Effective water & 31 & 30 & 31 & 30 & 23 & 0 & 78.8 \\
\hline & Water stress & 0 & 0 & 0 & 0 & 0 & 0 & $\mathbf{0}$ \\
\hline & Unavailable water & 0 & 0 & 0 & 0 & 0 & 0 & $\mathbf{0}$ \\
\hline \multirow{4}{*}{$100-120$} & Superfluous water & 0 & 0 & 0 & 0 & 6 & 31 & 20.11 \\
\hline & Effective water & 31 & 30 & 31 & 30 & 25 & 0 & 79.89 \\
\hline & Water stress & 0 & 0 & 0 & 0 & 0 & 0 & $\mathbf{0}$ \\
\hline & Unavailable water & 0 & 0 & 0 & 0 & 0 & 0 & $\mathbf{0}$ \\
\hline \multirow{4}{*}{$120-150$} & Superfluous water & 0 & 0 & 0 & 0 & 0 & 17 & 9.24 \\
\hline & Effective water & 31 & 30 & 31 & 30 & 31 & 14 & 90.76 \\
\hline & Water stress & 0 & 0 & 0 & 0 & 0 & 0 & 0 \\
\hline & Unavailable water & 0 & 0 & 0 & 0 & 0 & 0 & $\mathbf{0}$ \\
\hline
\end{tabular}

\section{Quantitative analysis of soil water status in cropland}

As can be seen from Table 4, the soil water excess period was 7 days, the water susceptibility period was 98 days, the water stress period was 73 days, and the water 
ineffective period was 6 days in $0-10 \mathrm{~cm}$ soil layer during the growth period of apple trees, which accounted for $3.80 \%, 53.26 \%, 39.67 \%$, and $3.27 \%$ of the apple trees growth period, respectively. Soil water accumulation in the excess period, water susceptibility period, water stress period, and water ineffective period accounted for $20.10 \%, 46.20 \%, 32.61 \%$, and $1.09 \%$ in the $10-20 \mathrm{~cm}$ soil layer. Compared to the $0-10$ $\mathrm{cm}$ soil layer in the rainy season, the soil water of the 10-20 cm soil layer was retained and the number of days in water excess increased significantly, which may be directly related to the tightening of the subsurface soil of croplands after the land reclamation, the increase of soil bulk density, the use of chemical fertilizers, and the shallow rotary tillage over many years (Zhu, 2014; Wang et al., 2017). Compared to the 0-20 cm soil layer, the spring soil drought increased significantly in the $20-40 \mathrm{~cm}$ soil layer and there was also a long period of soil layer water retention and excess water similar to the 10 $20 \mathrm{~cm}$ soil layer in the rainy season, which reflected the compaction of cropland soil.

Compared to the $0-40 \mathrm{~cm}$ soil layer, there was no excess water in the $40-60 \mathrm{~cm}$ soil layer. The soil drought in spring was more serious, and the water ineffective period had a longer duration, which indicated that crops were threatened by drought. There was no water ineffective period in the $60-80 \mathrm{~cm}$ soil layer during apple tree growth, where the drought had been relatively eased compared to the $20-60 \mathrm{~cm}$ soil layer.

In the 80-100 cm soil layer, there were 34 days of excess soil water, 121 days of water susceptibility, and 29 days of water stress during apple tree growth. In the 100$120 \mathrm{~cm}$ soil layer, there were 25 days of excess soil water, 152 days of water susceptibility, and 7 days of water stress, which accounted for $13.59 \%, 82.61 \%$, and $3.81 \%$ of the apple tree growth period, respectively. There was no water ineffective period in the $80-120 \mathrm{~cm}$ soil layer. There were 8 days with excess soil water and 176 days of water susceptibility, which accounted for $4.35 \%$ and $95.65 \%$ of the apple tree growth period.

During the apple tree growth period, the cropland soil drought mainly occurred from the spring to the early summer. The drought was more serious in the $20-60 \mathrm{~cm}$ soil layer, especially in the $40-60 \mathrm{~cm}$ soil layer, and the soil water stress gradually decreased below $60 \mathrm{~cm}$. The water retention period in the $10-40 \mathrm{~cm}$ soil layer was longer than that of the $0-10 \mathrm{~cm}$ surface layer, which indicated that compaction was a problem and water conduction was blocked. In the rainy season, there was a phenomenon of excessive water retention in the soil section to varying degrees, so the "internal dry soil layer" can be reclaimed during the rainy season.

\section{Quantitative analysis of soil water status in orchard}

As can be seen from Table 5, the soil water content was always accessible in the 0 $10 \mathrm{~cm}$ soil surface from mid-March to mid-July. However, the days of effective soil water were reduced to 12 days from mid-July to mid-September. Due to the rainy season, the soil water in the $0-10 \mathrm{~cm}$ soil layer was in a surplus for up to 50 days, accounting for $27.17 \%$ of the total days of apple tree growth. There was no water stress period. Excessive water at the surface provided a prerequisite for replenishing water in deep soil. From mid-March to mid-July, the soil water content in the $10-20 \mathrm{~cm}$ soil layer had been in effective water state. From mid-July to mid-September, the days of effective water decreased in lieu of excess water, which occurred for 35 days in total and accounted for $19.02 \%$ of the total days of apple tree growth. The soil water susceptibility in the $20-40 \mathrm{~cm}$ soil layer accounted for $83.43 \%$ of the apple tree growth 
period. From mid-July to mid-September, water surplus occurred for 36 days and accounted for $19.57 \%$ of the total days of apple tree growth.

The water content in the 40-60 cm soil layer was water-susceptible from mid-March to mid-July. Other than the water-susceptibility period, excess water occurred in 8 days from mid-July to mid-September, accounting for $4.35 \%$ of the apple tree growth period. The water content in the $60-80 \mathrm{~cm}$ soil layer had been in a state of water efficiency during apple tree growth period.

The $80-100 \mathrm{~cm}$ soil layer was effective water state from mid-March to mid-July. Excess water occurred in 39 days from mid-July to mid-September, accounting for $21.2 \%$ of the apple tree growth period. The soil water content in the $100-120 \mathrm{~cm}$ soil layer was mostly in a water-susceptible state during apple tree growth. Excess water occurred in 37 days, accounting for $20.11 \%$ of the apple tree growth period. In addition to the water-susceptible state, there was also a water surplus period of 17 days in the $120-150 \mathrm{~cm}$ soil layer, which accounted for $9.24 \%$ of the total days during apple tree growth.

The soil water status of orchards during the growth period of apple trees was not affected by water stress and there was deep movement of soil water during the rainy season after the reclamation of hollow villages in Weibei area.

\section{Analysis of soil water stress in croplands and orchards}

We also found that cropland soil water stress after hollow village reclamation was significantly stronger than that of orchards in Weibei rainfed highland. Adjusting the existing agricultural structure by converting large areas of cropland into orchards alleviated the sharp distinction between natural precipitation and soil water mitigation (Glaser et al., 2013). Further statistical analysis of Tables 4 and 5 showed that orchard soil water content did not reach the level of water stress and water ineffectiveness in the 0-150 cm soil profile. However, cropland experienced soil water stress throughout the entire $120 \mathrm{~cm}$ soil profile. Some studies previously found that the total water requirement for growing apples in Weibei area was about $500 \mathrm{~mm}$ (Wang and Zhang, 2000). However, the average daily water requirement for wheat has been estimated to be about $5 \mathrm{~mm}$ (Wang et al., 2018).

The percentage of days of effective soil water in apple tree growth period tended to decrease in the top soil layers then increase with soil depth, which accorded with the polynomial variation law of $y=1.54 \times 2-7.18 x+55.96$ (where $y$ is the percentage of water equivalent days, $\%, \mathrm{x}$ is the soil depth, $\left.\mathrm{cm}, \mathrm{R}^{2}=0.9587\right)$. The length of cropland water stress in the $20-40 \mathrm{~cm}$ soil layer was longer than the water susceptibility time, in which the existence of such long-term water stress made it extremely difficult to recover without precipitation or irrigation. The number of days of excess water in croplands was significantly less than that in orchards between mid-July to mid-September, which indicated that water stress in croplands was stronger than orchards and that recovery was more difficult. Trees canopies can suppress evaporation from the soil more so than croplands, which can greatly alleviate the problem of soil water stress caused by improper crop selection after reclamation. However, after the apple harvest, soil water consumption in orchards fall after fruit production and leaf drop. Thus, the excess water from the autumn rainy season may cause short-term waterlogging, which suggests that attention should be given to improving soil water permeability when planting apple trees (Nolz et al., 2014). 


\section{Conclusions}

(1) After the reclamation of hollow villages, the soil water content of orchards was significantly higher than that of croplands due to the difference in the amount and timing of water demanded by these land use types.

(2) There was no soil drought stress in orchards during the growth period. More specifically, the soil water content throughout the $0-150 \mathrm{~cm}$ soil profile was stable between field capacity and capillary water content (stress point). On the contrary, the soil drought in croplands was severe in degree, length, and depth from spring to early summer. Soil water stress lasted for 78 days in the $20-40 \mathrm{~cm}$ soil layer. The soil water content was below the permanent wilting coefficient for 42 days in the $40-60 \mathrm{~cm}$ soil layer.

(3) There was a significant drought in the entire $0-120 \mathrm{~cm}$ soil profile from midApril to mid-July, especially before the rainy season between mid-May and mid-July, and water stress was most likely to occur in the $20-60 \mathrm{~cm}$ soil layer.

Therefore, future study should focus on the development of soil water conservation technologies in the Weibei rainfed highland after the reclamation of hollow villages. In particular, the results obtained in this study indicate that vegetation coverage has a pronounced effect on soil water conditions in the reclaimed land. Therefore, it is necessary to strengthen the research regarding the selection and effect of "cover crops" based on water-saving technologies such as straw mulching and plastic mulching that have been applied extensively. An effective approach to inhibit water consumption via evaporation from land surface is to select suitable cover crops based on local climate conditions and minimize the exposure time of bare croplands as much as possible.

Acknowledgments. This work was financially supported by the Fundamental Research Funds for the Central Universities, CHD "Study on the plant cover influence on soil moisture in Weibei rainfed highland, northwest China".

\section{REFERENCES}

[1] Brocca, L., Melone, F., Moramarco, T., Morbidelli, R. (2010): Spatial-temporal variability of soil moisture and its estimation across scales. - Water Resour. Res. 46(2): W02516.

[2] Chen, H. S., Shao, M. A., Li, Y. Y. (2008): Soil desiccation in the Loess Plateau of China. - Geoderma 143(1): 91-100.

[3] Chen, Q., Liu, S. J., Bai, Y., Li, Y. X., Hao, C. H., Zhang, Q., Li, J. H. (2014): Screening and identification of phosphate-solubilizing bacteria from reclaimed soil in Shanxi mining area. - Plant Nutr. Fert Sci. 20(6): 1505-1516.

[4] Cheng, L. S., Feng, W. Y., Jiang, L. H. (2001): The analysis of rural settlement hollowizing system of the southeast of Taiyuan basin. - Acta Geogr. Sin. 56(4): 437-446.

[5] Dörner, J., Huertas, J., Cuevas, J. G., Leiva, C., Paulino, L., Arumí, J. L. (2015): Water content dynamics in a volcanic ash soil slope in southern Chile. - J. Plant Nutr. Soil Sci. 178: 693-702.

[6] Famiglietti, J. S., Ryu, D., Berg, A. A., Rodell, M., Jackson, T. J. (2008): Field observations of soil moisture variability across scales. - Water Resour. Res. 44(1): 186192.

[7] Fan, W. H., Bai, Z. K., Li, H. F., Qiao, J. Y., Xu, J. W. (2011): Effects of different vegetation restoration patterns and reclamation years on microbes in reclaimed soil. Trans. Chin. Soc. Agric. Eng. 27(2): 330-336. 
[8] Feng, W. Y., Chen, X. M. (2003): Analysis on the rural settlement expansion of the Jinzhogn plain. - Human Geogr. 18(6): 93-96.

[9] Gardner, W. H. (1965): Water Content. - In: Black, C. A. (ed.) Methods of Soil Analysis. Monograph 9. Am. Soc. Agron., Madison. WI, pp. 82-127.

[10] Glaser, B., Jentsch, A., Kreyling, J., Beierkuhnlein, C. (2013): Soil-moisture change caused by experimental extreme summer drought is similar to natural inter-annual variation in a loamy sand in Central Europe. - J. Plant Nutr. Soil Sci. 176: 27-34.

[11] Grayson, R. B., Western, A. W. (1998): Towards areal estimation of soil water content from point measurements: time and space stability of mean response. - J. Hydrol. 207(12): 68-82.

[12] Guber, A. K., Gish, T. J., Pachepsky, Y. A., Genuchten, M. T. V., Daughtry, C. S. T., Nicholson, T. J. (2008): Temporal stability in soil water content patterns across agricultural fields. - Catena. 73(1): 125-133.

[13] Guo, X. Y., Zhang, J. T., Gong, H. L., Zhang, G. L., Dong, Z. (2005): Analysis of changes of the species diversity in the process of vegetation restoration in Antaibao mining field, China. - Acta Ecol. Sin. 25(4): 763-770.

[14] Jacobs, J. M., Mohanty, B. P., Hsu, E. C., Miller, D. (2004): Smex02: field scale variability, time stability and similarity of soil moisture. - Remote Sens. Environ. 92(4): 436-446.

[15] Kim, G., Barros, A. P. (2002): Space-time characterization of soil moisture from passive microwave remotely sensed imagery and ancillary data. - Remote Sens. Environ. 81: 393-403.

[16] Lei, Z. D. (2002): Ruual habitat empty-disusing concept and quantitative analysis model. - J. Northwest Univ. (Nat. Sci. Ed.). 32(4): 421-424.

[17] Li, J., Li, X. J. (2008): The microscopic analysis on village-hollowing in medium income and hilly land region of Henan province. - Chin. Popul. Resour. Environ. 18(1): 170-175.

[18] Nolz, R., Cepuder, P., Kammerer, G. (2014): Determining soil water-balance components using an irrigated grass lysimeter in NE Austria. - J. Plant Nutr. Soil Sci. 177: 237-244.

[19] Qian, K. M., Wang, L. P., Li, J. (2011): Variation of microbial activity in reclaimed soil in mining area. - J. Ecol. Rura. Environ. 27(6): 59-63.

[20] Vachaud, G., Silans, A. P. D., Balabanis, P., Vauclin, M. (1985): Temporal stability of spatially measured soil water probability density function. - Soil Sci. Soc. Am. J. 49(4): 822-828.

[21] Vereecken, H., Kamai, T., Harter, T., Kasteel, R., Hopmans, J., Vanderborght, J. (2007): Explaining soil moisture variability as a function of mean soil moisture: a stochastic unsaturated flow perspective. - Geophys. Res. Lett. 34(22): 315-324.

[22] Wang, C. X., Yao, S. M., Chen, C. H. (2005): Empirical study on "village-hollowing" in China. - Sci. Geogr. Sin. 25(3): 257-262.

[23] Wang, J. (2019): Short-term geochemical investigation and assessment of dissolved elements from simulated ash reclaimed soil into groundwater. - Environ. Pollut. 247: 302-311.

[24] Wang, J. Q., Liu, X. Y., Cheng, K., X. H., Zhang, Li, L. Q., Pan, G. X. (2018): Winter wheat water requirement and utilization efficiency under simulated climate change conditions: a Penman-Monteith model evaluation. - Agr. Water Manage. 197: 100-109.

[25] Wang, J. X., Zhang, X. P., Gao, B. S., He, X. X. (2000): Study on wager requirement and limited irrigation effects of dwarfing red fuji apple tree on Weibei of Loess Plateau. Res. Soil Water Conserv. 7(1): 69-72.

[26] Wang, J. X., Wang, Y. Q., Li, X., Liang, H. W., Shi, H. P., Shi, Z. L. (2017): Evaluation of soil physical state in Guanzhogn cropland. - Agric. Res. Arid Areas. 35(3): 245-252.

[27] Wang, Y. Q., Shao, M. A., Liu, Z. P. (2012): Spatial variability of soil moisture at a regional scale in the Loess Plateau. - Advan. Water Sci. 23(3): 310-316.

[28] Xu, S. H. (2004): The integral regimes and countermeasure study on hollow-oriented houses in rural regions. - Terri. Nat. Res. 1: 11-12. 
[29] Xue, L., Wu, M. W. (2001): Spatial differentiation and countermeasures of rural people's environment construction in Jiangsu province. - J. Urban Plan. 1: 41-45.

[30] Xunyi County Chronicle Compilation Committee (2018): Xunyi County Annals. - San Qin Press, Xi'an.

[31] Zhong, Z. M. (2008): Analysis on the causes and treatment of rural homestead idle. Agricul. Econ. 6: 57-58.

[32] Zhu, F. H. (2014): The degradation features of cropland soil physical and its harmfulness in Guanzhong area. - Northwest A \& F University, Yangling.

[33] Zhu, X. H., Chen, Y. F., Liu, Y. S., Zhang, J., Li, Y. Y., Ding, J. J. (2010): Technique and method of rural land consolidation potential investigation and assessment. - Acta Geogr. Sin. 25(6): 736-744. 